\title{
Susceptibility of Human Pathogenic Bacteria to Antimicrobial Peptides from Sesame Kernels
}

\author{
Fábio Teles Costa, ${ }^{1}$ Simone Maria Neto, ${ }^{1}$ Carlos Bloch Jr., ${ }^{2}$ Octávio Luiz Franco ${ }^{1}$ \\ ${ }^{1}$ Centro de Análises Proteômicas e Bioquímicas, Programa de Pós-Graduação em Ciências Genômicas e Biotecnologia, \\ Universidade Católica de Brasília, SGAN, Quadra 916, Módulo B, Av. W5 Norte, 70.790-160, Asa Norte, Brasília-DF, Brazil \\ ${ }^{2}$ Laboratório de Espectrometria de Massa, Embrapa Recursos Genéticos e Biotecnologia, Parque Estação Biológica, Final W5, 70.770-900, \\ Asa Norte, Brasília-DF, Brazil
}

Received: 1 March 2007 / Accepted: 19 March 2007

\begin{abstract}
Hospital infection caused by Gram-negative bacteria is a serious and common problem, especially in developing countries. Aiming to reduce these infections, this report focuses on the identification and characterization of novel antimicrobial peptides from sesame (Sesamum indicum) kernel meals. Thus, sesame flour was extracted and precipitated with ammonium sulfate (100\%). After dialysis, a rich fraction was applied to affinity red-Sepharose CL-6B chromatography, followed by reversedphase high-performance liquid chromatography. Mass spectrometry analysis indicated the presence of a major peptide with molecular mass of $\sim 5.8 \mathrm{kDa}$ in both cultivars. The bactericidal activities of antimicrobial peptides were evaluated against several human pathogens that had been effective only against Klebsiella sp., a Gram-negative bacterium responsible for human urinary infection. These data indicate the biotechnological potential of sesame peptides as an alternative method for hospital infection control and also the decrease of bacterial resistance to synthetic antibiotics.
\end{abstract}

Sesame (Sesamum indicum L.) is an older oleaginous kernel that has been commonly used by several nations as a source of food and medicines [1-3]. Including sesame, all living organisms are able to develop selfdefense mechanisms against pathogen attack. Among these defenses, were included important compounds such as phenols, secondary compounds, and antimicrobial peptides (AMPs) [4]. Antimicrobial peptides have been isolated from insects [5, 6], mammals [7], microorganisms [8], and several plant tissues such as leaves, flowers, and seeds [4]. In the large AMP class, several families are included, such as defensins [9], 2S albumins [10], vicilins [11], and several others. All of them contribute to plant innate host defense and represent an important source for antibiotics. Most of these peptides show the ability to bind on lipids of the cell surface, to induce cell permeability, and to cause enhanced lethality to pathogenic bacteria [12-14].
On the other side, an uncontrolled increase of pathogens with antibiotic resistance, including several Gram-negative bacteria such as Escherichia coli, Klebsiella sp., and Proteus sp., is the cause of a serious problem known as hospital infection [15]. These lethal infections, commonly observed in developing countries, have led to a search for new strategies to control these infectious agents. A primary search has been focused on AMPs, since these peptides have shown high activity against pathogens but low toxicity against mammalian cells $[14,16]$. In this report, cationic antimicrobial peptides from $S$. indicum kernels of black and white cultivars (AMP-SiB and AMP-SiW) were purified and characterized, and their ability to control human pathogenic Gram-negative was evaluated.

\section{Materials and Methods}

Extraction and Isolation of $S$. indicum Kernels Peptides. Kernels of two sesame (S. indicum) cultivars (black and white) were evaluated. Seeds were washed with sanitary water (30\% solution) for $5 \mathrm{~min}$ 
followed by distilled water for another $5 \mathrm{~min}$. Sesame kernel meals were extracted with a solution containing $0.6 \mathrm{M} \mathrm{NaCl}$ and $0.1 \% \mathrm{HCl}$, in a proportion of $1: 3(\mathrm{w} / \mathrm{v})$, for $6 \mathrm{~h}$ at $4^{\circ} \mathrm{C}$. This crude extract was centrifuged at $4000 \mathrm{~g}$ for $2 \mathrm{~h}$ at $4^{\circ} \mathrm{C}$. Proteins in the supernatant were precipitated with $\left(\mathrm{NH}_{4}\right)_{2} \mathrm{SO}_{4}$ at $100 \%$ saturation with constant stirring. After centrifugation (under equal conditions), the precipitate was resuspended and dialyzed (3.0 kDa cut off) against distilled water. A rich fraction was lyophilized and $5 \mathrm{mg}$ of soluble protein was applied onto affinity red-Sepharose CL-6B chromatography, equilibrated with buffer A $\left(0.1 \mathrm{M}\right.$ Tris- $\mathrm{HCl}$, $\mathrm{pH} 7.0$, containing $\left.0.05 \mathrm{M} \mathrm{CaCl}_{2}\right)$. Nonretained proteins (NRP) were displaced with the same buffer. Retained proteins (RP) were eluted with buffer B $(0.1 \mathrm{M}$ Tris- $\mathrm{HCl}, \mathrm{pH} 7.0$, containing $3.0 \mathrm{M}$ $\mathrm{NaCl}$ ). Protein elution was analyzed at $280 \mathrm{~nm}$. RP was dialyzed, lyophilized, resuspended with $0.1 \%$ trifluoroacetic acid (TFA), and applied to analytical reversed-phase high-performance liquid chromatography (HPLC) (Vydac C-18TP 522) where the retained fraction was eluted using a linear gradient of acetonitrile $(0-100 \%)$ at a flow rate of $1.0 \mathrm{~mL} / \mathrm{min}$.

Molecular Mass Analyses. Protein fractions were analyzed by $12 \%$ sodium dodecyl sulfate-polyacrylamide gel electrophoresis (SDSPAGE) according Laemmli [17]. Gels were silver stained and bromophenol blue was used as the tracking dye. AMP-Si was also submitted to mass spectrometry analyses according Franco et al. [9].

Bioassays. Klebsiella sp., Proteus sp., and E. coli were challenged by use of $1.0 \mathrm{~mL}$ of Luria-Bertani (LB) broth $(10 \mathrm{~g} / \mathrm{L} \mathrm{NaCl}, 5 \mathrm{~g} / \mathrm{L}$ yeast extract, and $45 \mathrm{~g} / \mathrm{L}$ bactopeptone). The bacteria were grown in $\mathrm{LB}$ broth for $18-24 \mathrm{~h}$ at $37^{\circ} \mathrm{C}$ before starting peptide evaluation. Distilled water was used as the negative control and $40 \mu \mathrm{g} / \mathrm{mL}$ chloranphenicol was used as the positive control. The protein fractions eluted from reversed-phase chromatography were incubated with Gram-negative bacteria on LB broth for $4 \mathrm{~h}$ at $37^{\circ} \mathrm{C}$ at standard concentrations of $10,25,50$, and $100 \mu \mathrm{g} / \mathrm{mL}$. Evaluation of bacteria growth was done by spectrophotometric analyses at $595 \mathrm{~nm}$, for each experimental hour. Each experiment was carried out in triplicate.

\section{Results}

Purification of AMP-Sis. In order to identify novel antimicrobial peptides in sesame kernels, crude extracts from both cultivars were challenged against human pathogenic bacteria. After enrichment, these fractions were applied to affinity Red-Shepharose CL-6B chromatography (Fig. 1A), which is commonly utilized to purify cationic and hydrophobic peptides $[10,18,19]$. Only retained protein fractions from white and black cultivars were capable of reducing Proteus sp. and Klebsiella sp. growths (data not shown). After dialyses, RP was submitted to a reversed-phase HPLC (Figs. 1B and 1C). The white sesame cultivar showed a major peak at $18 \%$ acetonitrile, whereas the black sesame cultivar presented antibacterial proteins eluted in a major peak of $23 \%$ acetonitrile.

Molecular Mass Analysis. The SDS-PAGE analyses of HPLC major peaks showed single bands for both cultivars that correspond to proteins with $\sim 5 \mathrm{kDa}$ (data not shown). This result was confirmed by mass
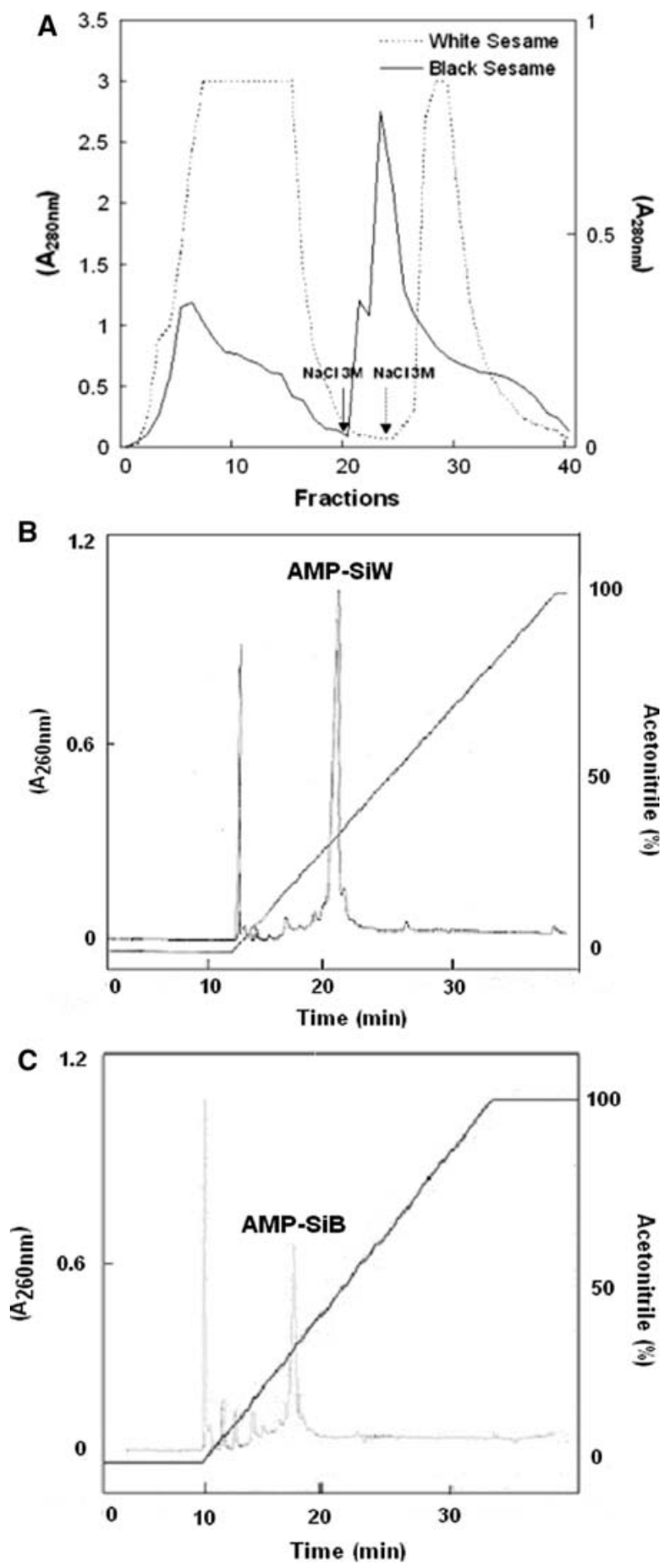

Fig. 1. A Red-Sepharose chromatographic profiles of white (dotted line) and black (solid line) sesame kernels. NRP corresponds to the nonretained peak and RP to the retained one. Black arrows indicate a single elution step of $3.0 \mathrm{M} \mathrm{NaCl}$. Therefore, white and black RPs were applied to a reversed-phase HPLC-generating chromatographic profiles (B) and (C), respectively. Diagonal lines indicate acetonitrile gradient elution $(0-100 \%)$. 

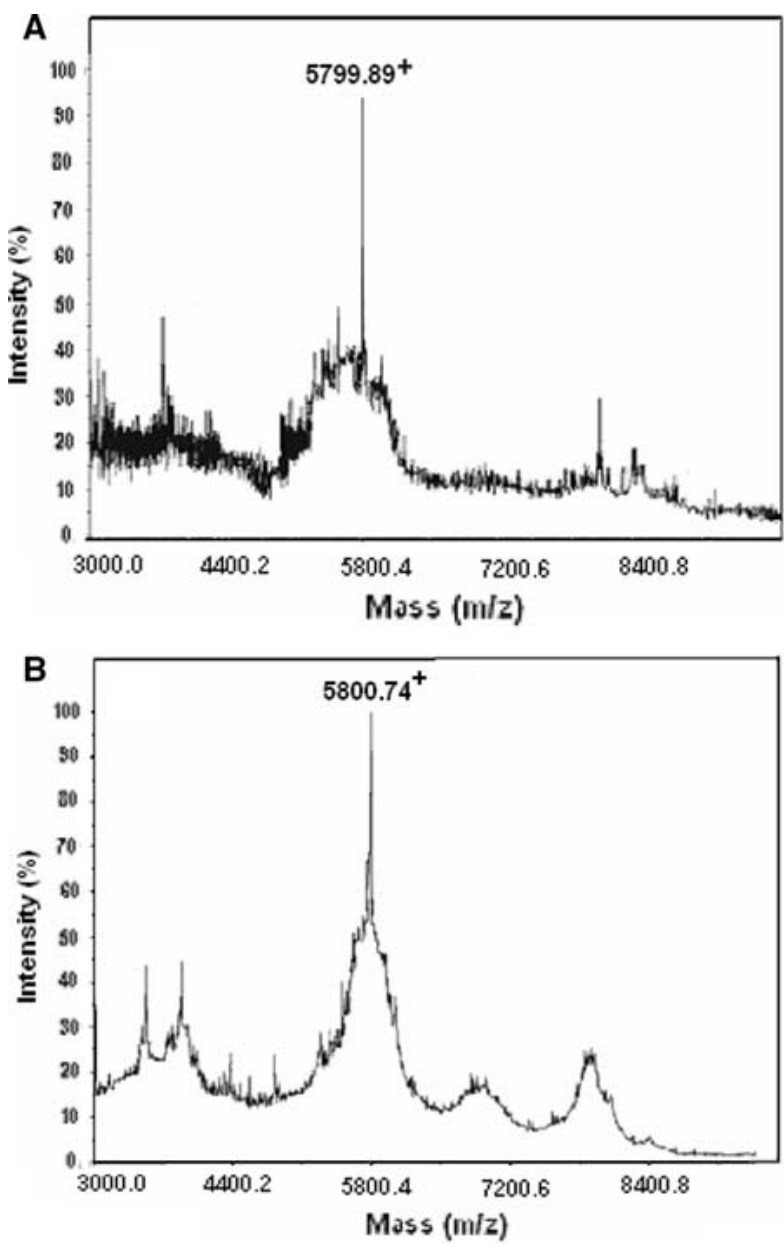

Fig. 2. Matrix assisted laser desorption/ionization time-flight spectra of AMP-Sis from white (A) and (B) black cultivars.

spectrometric analysis, where was observed two peptides of 5799.69 and 5800.74 Daltons, respectively, from black and white cultivars (Figs. 2A and 2B) were observed, denoted AMP-SiB and AMP-SiW, respectively.

Biological Activity. Crude extract was evaluated against the three Gram-negative bacteria previously described, at a standard concentration of $100 \mu \mathrm{g} / \mathrm{mL}$. However, this extract was only active against Klebsiella sp., being capable of reducing their development by 50\% (data not shown). Moreover, purified peptides obtained from HPLC fractions were compared against Gram-negative bacteria. AMP-SiW and AMP-SiB were capable of inhibiting $\sim 25 \%$ of Klebsiella sp. growth (Figs. 3A and 3B) at concentration of $100 \mu \mathrm{g} / \mathrm{mL}$. Nevertheless, at lower concentrations $(10,25$, and 50 $\mu \mathrm{g} / \mathrm{mL}$ ) no activity was observed. Furthermore, no deleterious activity of purified peptides was observed against Proteus sp. and E. coli (data not shown).
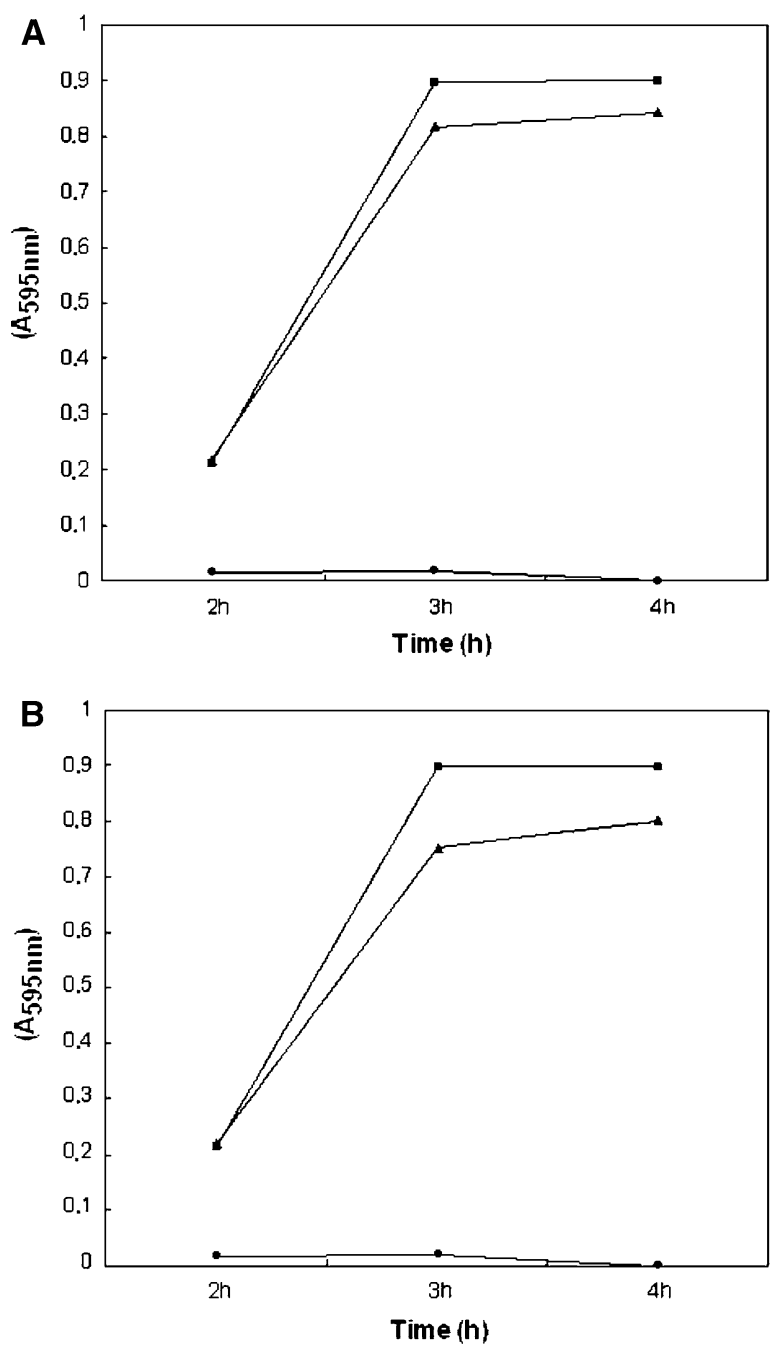

Fig. 3. Antimicrobial activities of AMP-Sis from white (AMP-SiW) (A) and black (AMP-SiB) (B) sesame kernels are indicated by black triangles. Black squares correspond to the negative control (distilled water) and black circles correspond to the positive control (chloranphenicol, $40 \mu \mathrm{g} / \mathrm{mL}$ ). Vertical bars correspond to the standard deviation. Each assay was carried out in triplicate.

\section{Discussion}

In spite of the sesame peptides reported here being unpublished, similar biochemical properties have been found in other bactericidal peptides. Among them we could observe similarities in the acetonitrile concentrations elution, as in the isolation of antimicrobial peptides from Japanese bamboo shoots (Phyllostachys pubenscens) [20], bulbs of the tulip (Tulipa gesneriana L.) [21], buckwheat seeds (Fagopyrum esculentum M.) [22], passion fruit seeds (Passiflora edulis) [10], cowpea seeds (Vigna unguiculata) [9-19], macadamia nut kernels (Macadamia integrifolia) [11], and radish seeds (Raphanus sativus L.) [23]. Also, molecular masses 
were similar when compared to $\mathrm{Cp}$-thionins from $V$. unguiculata seeds [9, 19] and 2S albumins from $P$. edulis [10]. Both classes show antimicrobial properties. AMP-Sis masses are similar to molecular weights observed in different antimicrobial peptide classes. For this reason, at this moment and using this parameter, it is impossible to classify them correctly. Further sequencing experiments will be conduced in order to elucidate this specific property.

Furthermore, AMP-SiB and AMP-SiW showed inhibitory activity against Klebsiella sp. Similar results were obtained by using antimicrobial peptides from different plant sources, such as cowpea seeds [9]. In this study, it was shown that cowpea peptide was active against both Gram-positive and Gram-negative bacteria [9]. Otherwise, several AMPs showed inhibitory activity against a wide variety of pathogenic micro-organisms, which included fungi, bacteria, and protozoa, indicating the enormous biotechnological potential of AMPs [10, 13, 21-23]. Moreover, it was observed that the expression of an antimicrobial peptide from motherwort (Leonurus japonicus Houtt) was able to promote disease resistance in tobacco [24].

Hence, our results showed severe growth inhibition of the human pathogen Klebsiella sp., a bacterium responsible for urinary and lung infections in weakened hospital patients. These data suggest that the development of new drugs from AMPs might be successful for the treatment of several infections, reducing hospital costs and also human mortality. The results observed here are quite encouraging, when compared with other AMPs with activities against Gram-negative bacteria. In addition, this research indicated the remarkable potential of the unexploited genetic resources of plant biodiversity. The discovery of valuable genes in plant biodiversity might also be an alternative for countries in development which have biotechnological research but have difficulties accessing novel drugs due to elevated costs and also patent restrictions.

\section{ACKNOWLEDGMENTS}

We would thank Dra. Silvia E. T. Bittencourt and the entire Centro de Análises Proteômicas e Bioquímicas (CAPB) team for technical assistance. This work was supported by CAPES, FAPEMIG, CNPq, and UCB.

\section{Literature Cited}

1. Hsiao ES, Lin LJ, Li FY (2006) Gene families encoding isoforms of two major sesame seed storage proteins, $11 \mathrm{~S}$ globulin and $2 \mathrm{~S}$ albumin. J Agric Food Chem 54:9544-9550

2. Hu Q, Xu J, Chen S (2004) Antioxidant activity of extracts of black sesame seed (Sesamum indicum L.) by supercritical carbon dioxide extraction. J Agric Food Chem 52:943-947
3. Kobayashi S, Watanabe J, Kawabata J (2004) A novel method for producing a foodstuff from defatted black sesame seed that inhibits allergen absorption. Biosci Biotechnol Biochem 68:300530

4. Pelegrini PB, Franco OL (2005) Plant $\gamma$-thionins: novel insights on the mechanism of action of a multi-functional class of defense proteins. Int J Biochem Cell Biol 37:2239-2253

5. Casteels P, Ampe C, Jacobs F (1993) Functional and chemical characterization of Hymenoptaecin, an antibacterial polypeptide that is infection-inducible in the honeybee (Apis mellifera). J Biol Chem 268:7044-7054

6. Wang JX, Zhao XF, Liang YL (2006) Molecular characterization and expression of the antimicrobial peptide defensin from the housefly (Musca domestica). Cell Mol Life Sci 63:3072-3082

7. Xiao Y, Hughes AL, Ando J (2004) A genome-wide screen identifies a single beta-defensin gene cluster in the chicken: implications for the origin and evolution of mammalian defensins. BMC Genomics 5:56

8. Bizani D, Dominguez AP, Brandelli A (2005) Purification and partial chemical characterization of the antimicrobial peptide cerein 8A. Lett Appl Microbiol 41:269-273

9. Franco OL, Murad AM, Leite JR (2006) Identification of a cowpea $\gamma$-thionin with bactericidal activity. FEBS J 273:3489-3497

10. Pelegrini PB, Noronha EF, Muniz MA (2006) An antifungal peptide from passion fruit (Passiflora edulis) seeds with similarities to 2 S albumin proteins. Biochim Biophys Acta 1764:11411146

11. Marcus JP, Green JL, Goulter KC (1999) A family of antimicrobial peptides is produced by processing of a $7 \mathrm{~S}$ globulin protein in Macadamia integrifolia kernels. Plant J 19:699-710

12. Nagaoka I, Hirota S, Niyonsaba F (2001) Cathelicidin family of antibacterial peptides CAP18 and CAP11 inhibit the expression of TNF-alpha by blocking the binding of LPS to CD14(+) cells. J Immunol 167:3329-3338

13. Prates MV, Sforca ML, Regis WC (2004) The NMR-derived solution structure of a new cationic antimicrobial peptide from the skin secretion of the anuran Hyla punctata. J Biol Chem 279:13,018-13,026

14. Hagge SO, Hammer MU, Wiese A (2006) Calcium adsorption and displacement: characterization of lipid monolayers and their interaction with membrane-active peptides/proteins. BMC Biochem 3:7-15

15. Paterson DL (2006) Resistance in gram-negative bacteria: Enterobacteriaceae. Am J Infect Control 34(Suppl 1):S20-S28

16. Bechinger B (1999) The structure, dynamics and orientation of antimicrobial peptides in membranes by multidimensional solidstate NMR spectroscopy. Biochim Biophys Acta 15:157-183

17. Laemmli UK (1970) Cleavage of structural proteins during assembly of the head of the bacteriophage $T_{4}$. Nature 227:680 685

18. Bloch C Jr, Richardson M (1991) A new family of small (5 kDa) protein inhibitors of insect alpha-amylases from seeds or sorghum (Sorghum bicolor (L.) Moench) have sequence homologies with wheat $\gamma$-purothionins. FEBS Lett 11:101-104

19. Melo FR, Sales MP, Pereira LS (1999) $\alpha$-Amylase inhibitors from cowpea seeds. Prot Pept Lett 6:385-390

20. Fujimura M, Ideguchi M, Minami Y (2005) Amino acid sequence and antimicrobial activity of chitin-binding peptides, Pp-AMP 1 and Pp-AMP 2, from Japanese bamboo shoots (Phyllostachys pubescens). Biosci Biotechnol Biochem 69:642-645

21. Fujimura M, Ideguchi M, Minami Y (2004) Purification, characterization, and sequencing of novel antimicrobial peptides, $\mathrm{Tu}-$ 
AMP 1 and Tu-AMP 2, from bulbs of tulip (Tulipa gesneriana L.). Biosci Biotechnol Biochem 68:571-577

22. Fujimura M, Minami Y, Watanabe K (2003) Purification, characterization, and sequencing of a novel type of antimicrobial peptides, Fa-AMP1 and Fa-AMP2, from seeds of buckwheat (Fagopyrum esculentum Moench.). Biosci Biotechnol Biochem 67:1636-1642
23. Terras FR, Schoofs HM, De Bolle MF (1992) Analysis of two novel classes of plant antifungal proteins from radish (Raphanus sativus L.) seeds. J Biol Chem 267:15,301-15,309

24. Yang X, Xiao Y, Wang X (2007) Expression of a novel small antimicrobial protein from the seeds of motherwort (Leonurus japonicus) confers disease resistance in tobacco. Appl Environ Microbiol 73:939-946 